\title{
ENVIRONMENTAL LIFE CYCLE ASSESSMENT AND COST ANALYSIS OF AGGREGATE PRODUCTION INDUSTRIES COMPARED WITH HYBRID SCENARIO
}

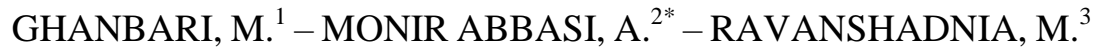 \\ ${ }^{I}$ Department of Construction Engineering and Management, Science and Research Branch, \\ Islamic Azad University, Tehran, Iran \\ (phone: +98-912-248-3367; e-mail: Milad.ghanbari@srbiau.ac.ir) \\ ${ }^{2}$ Department of Civil Engineering, Payame Noor University, Iran \\ (phone: +98-912-325-7962; e-mail: Monirabbasi@pnu.ac.ir) \\ ${ }^{3}$ Department of Construction Engineering and Management, Science and Research Branch, \\ Islamic Azad University, Tehran, Iran \\ (phone: +98-912-527-3422; e-mail: Ravanshadnia@srbiau.ac.ir) \\ *Corresponding author \\ e-mail: Monirabbasi@pnu.ac.ir; phone: +98-912-325-7962 \\ (Received $12^{\text {th }}$ Dec 2016; accepted $25^{\text {th }}$ May 2017)
}

\begin{abstract}
Aggregates are generally divided into three scenarios, depending on the production methods. The first scenario considers the production of natural aggregates (NA), while the second scenario views the production of recycled aggregates (RA) with construction and demolition (C\&D) waste. The third scenario, however, is a hybrid scenario which is the combination of NA and RA, assuming a mixing percentage of 50\%. In point of fact, the first scenario is the current policy implemented in many countries, whereas the second and the third scenarios are the proposed alternative options. The present study evaluates the environmental impacts and cost of the production of aggregates via each scenario, in a way that energy consumption, $\mathrm{CO}_{2}$ emissions and cost are considered as the main variables. The total cost encompasses the costs of investment, energy, and maintenance. To conclude, this research reveals that Iran's current policy with an annual energy consumption of 1.48 million tons of oil equivalent can have a footprint of 2.88 million tons CO2eq emissions per year and cost of 1301 million USD per year (the first scenario). Achieving 30\%, 36\% and 32\% reduction in annual energy consumption, $\mathrm{CO}_{2}$ emissions and total cost, respectively, by the third scenario compared to the first scenario unravels the destructive effect of the first scenario from environmental and economic perspectives.
\end{abstract}

Keywords: impact assessment, recycled aggregate, construction and demolition waste, $\mathrm{CO}_{2}$ emission, energy consumption

\section{Introduction}

In Australia, approximately 8.7 million tons of concrete demolition waste, 1.3 million tons of brick demolition waste, 3.3 million tons of rock excavation waste, 1 million tons of glass waste, and 1.2 million tons of asphalt pavement waste per year have been reported (Arulrajah et al., 2013). According to another report (Tam et al., 2010), $42 \%$ of the total waste in Australia is dedicated to construction and demolition (C\&D) waste; moreover, it is noticeable that concrete waste constitutes $81 \%$ of the C\&D waste in this country. Similarly, $29 \%$ of the solid waste in the USA is the C\&D waste (ibid). In the USA, approximately 30 million tons of concrete have to be discarded each year (Liang et al., 2013), a phenomenon which could be named as disposal. Thirty-eight percent of the total annual waste in Hong Kong equals 14 million tons, 11 million tons of which are utilized in public applications such as reclamation and 
embankment, while the remaining 3 million tons are buried in landfill (Tam et al., 2010). However, Japan is far more environment-friendly in this field, and only is $16 \%$ (approximately 750 thousand tons) of its total waste related to annual C\&D waste. This means that Japan prevents landfilling by its highly efficient construction waste recycling system (ibid). However, according to Huang et al. (2013), there are relations between population growth, urbanization, material demand, and waste generation. An accurate estimation of these relations strengthens future planning and computation accuracy.

Likewise, the C\&D waste generation in Iran is higher than that of other countries. According to the report prepared by Tehran Waste Management Organization (TWMO), the total rate of annual C\&D waste generation in Tehran is 15.33 million tons (about 42,000 tons per day) that are extremely difficult to be controlled and managed (TUPRC, 2013). A serious concern latent in the above-mentioned statistics is the uncontrolled exploitation of stone quarries to produce sand and gravel. This issue involves environmental risks and neglects the principles of sustainable development by converting the stone resources necessary for future generations to the demolition waste. In the USA, approximately 2 billion tons of aggregates are produced every year; additionally, this rate is expected to escalate up to 2.5 billion tons by 2020 (Harrington, 2005). Generally, annual production of building materials and products leads to consuming more than 3 billion tons of raw materials in the world (Saghafi and Teshnizi, 2011).

The industrial sector is believed to be one of the major sectors polluting the environment to such a large extent that $30 \%$ to $70 \%$ of the global energy consumption and $\mathrm{CO}_{2}$ emissions are related to the industrial (manufacturing) sector. This rate was approximately 500 million tons in 2012 in Iran (with an upward trend compared to that in 1990) (Oh et al., 2014). On the other hand, about $80 \%$ of greenhouse gas (GHG) emissions arise from energy production (Coelho and de Brito, 2013). These problems will not be solved unless the construction materials in construction tasks are reused, recycled, and reduced (3R) (Tam and Tam, 2006).

Studying the environmental impact of recycled construction materials such as plastic, polypropylene (Yin et al., 2016), iron, glass, cement, and others has been targeted around the world. Thus, recycling glass containers has resulted in a significant reduction by 27 and 37\% in energy consumption and GHG emissions, respectively (Vossberg et al., 2014). Correspondingly, one of the solutions for reducing the uncontrolled extraction of stone quarries is recycling aggregates, leading to decreasing energy consumption and GHG emissions (especially $\mathrm{CO}_{2}$ ). In addition to economic (Tam, 2008; Zhao et al., 2010) and environmental benefits (Oliveira et al., 2016), recycling aggregates is also feasible in terms of technical-quality criterion (Huang et al., 2002) so that it can be reused in concrete usage (Sabai et al., 2013) or construction of roads (Petkovic et al., 2004). Recycling, recycling C\&D waste in particular, is one of the key issues in implementing sustainable development that can reduce human health risks and, as Woon and Lo (2016) have stated, can be measured through life cycle human health (LCHH). Other attempts can encompass life cycle energy assessment (LCEA), life cycle carbon emissions assessment (LCCA) (Chau et al., 2015), life cycle cost (LCC) (Ristimäki et al., 2013; Mangan and Oral, 2016; Islam et al., 2015a), and life cycle environmental impact (LCEI) (Islam et al., 2015b). It is believed that the recycling industry in Iran has displayed a poor performance and is actually at the beginning of the path to development. As a developed country in the domain of recycling, Japan has enforced the relevant regulations and instructions to meet its environmental objectives 
(Liang et al., 2013). Furthermore, France has practiced sustainable development in the cultural aspects and has established the use of recycled materials in the fields of civil engineering and architecture (Sieffert et al., 2014).

Previous studies relating to aggregates production are focused primarily on construction concrete and secondly on life cycle assessment (LCA). Lack of considering cases such as energy and emission evaluation together with cost analysis and also assess of different scenarios include of natural, recycled and mixed aggregates in the previous studies are the research gap. The total cumulative energy demand in the production of aggregates will have a significant impact on the completed construction cost as well as energy price. In addition, the cumulative environmental impacts of the energy supply and the excessive exploitation of stone quarries authenticate the investigation. However, little attention has been paid to recycled aggregates. Indeed, this research assesses the environmental feasibility studies of setting up the recycling centers of aggregates in the landfill location of cities where landfills have created the environmental crisis. All of the above-mentioned cases show the gaps in the research into aggregates, which this study aims to cover .

The present study seeks to estimate the environmental variables (energy consumption and $\mathrm{CO}_{2}$ emissions) of the production of aggregates in comparison with the recycling alternatives. Furthermore, this research evaluates the economic feasibility of setting up recycling centers for aggregates in the landfill location of cities, where landfills have created environmental crises. For this purpose, the production scenarios of natural and recycled aggregates as well as the hybrid scenario are evaluated and compared.

This paper comprises five sections, including this introduction. The second section describes the scope of this study, including the description in detail of the life cycle assessment. The data collected section sets out the required information for environmental and cost analysis. A detailed presentation, analysis and discussing of the results achieved is included in the fourth section. The paper ends by summarising the main conclusions of this research study.

\section{Methodology and materials}

Evaluating the energy consumption and $\mathrm{CO}_{2}$ emissions is the most visible environmental criterion feasibility of recycling concrete measures (Oliveira et al., 2016). The scenarios of emissions include $\mathrm{CO}_{2}, \mathrm{CO}, \mathrm{CxHy}, \mathrm{NOx}$, and $\mathrm{SO}_{2}$ pollutants (Ping and Yidong, 2011). In this research, however, we only investigate energy consumption, $\mathrm{CO}_{2}$ emissions and other operating and investment costs related to the production of aggregates.

Therefore, $\mathrm{CO}_{2}$ emissions and energy consumption are the main environmental variables in the present study. Accordingly, the total cost is the economic variable. Computing the variables need the evalution the life cycle of aggregates which extraction and processing phases are more considerable in this research. On the other hand, research method of the most of the related previous studies in environmental impacts assessment is life cycle assessment (LCA) approach. To that end, concept of LCA approach is partially applied. Application of this approch in the present study is used and developed by Microsoft Excel software.

The stone materials are aggregates which depend on the size of these materials and are utilized in roads and construction development projects. The major applications of construction aggregates include roads and pavements (Petkovic et al., 2004; Arulrajah et 
al., 2014), housing (Lawania et al., 2015) and building (shells and structures), landscaping, and precast concrete parts (Sabai et al., 2013). The Iranians only use the natural stone materials and do not use recycled aggregates, because they are not supported by the government. For each type of the above-mentioned uses in any country, there is a related specification code and standard for aggregates, determining the size and type of grain. The Iranian National Standardization Organization (INSO, 2015) institute and the related technical publications (PMO, 2013) have defined the minimum and maximum range for each type of application based on Standard Specification for Concrete Aggregates (ASTM). In this study, the ranges determined are converted into non-logarithmic grain curves to gain a conceptual understanding. Fig. 1 depicts the grain curve of standard NA for buildings concrete applications. The grain curve of the aggregates selected should be between the minimum and maximum range in order to achieve a good grain in this case.
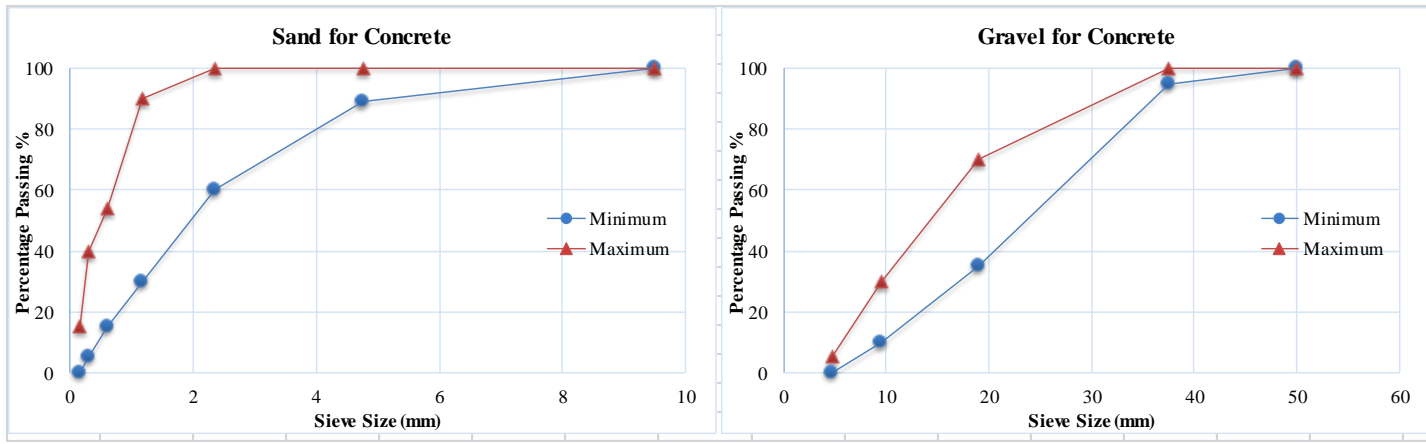

Figure 1. Grain curve of different aggregates (concrete applications)

\section{Goal, scope and inventory modelling}

The awareness of energy consumption and $\mathrm{CO}_{2}$ emissions (the main environmental variables of the study) and total costs leads governmental organizations to reduce the utilization of stone resources (quarries). The schematic sketch of the production of aggregates is presented in Fig. 2. In point of fact, Fig. 2 can be considered as the conceptual model of the present research. In this research, only are the quarry_crushing plant and landfill_recycling plant phases explored. In addition, the detailed observation of Fig. 2 indicates the scope and inventory of LCA model. The scope of this research encompasses natural and recycled aggregates, energy consumption, $\mathrm{CO}_{2}$ emissions and cost, production of aggregates, and recycling plants.

An inventory (stock) evaluation requires a database. The existence of the data means creating a model, and each model contains inputs and outputs. In this study, the inputs data of the model include the production and recycling process of aggregates, the number, type, and specifications of the equipment, and the energy consumption. $\mathrm{CO} 2$ emissions and cost of each equipment. The outputs of model include total energy consumption, $\mathrm{CO} 2$ emissions and the total cost. The functional unit in this study is annual production of NA and/or RA by 480,000 tons/year. 


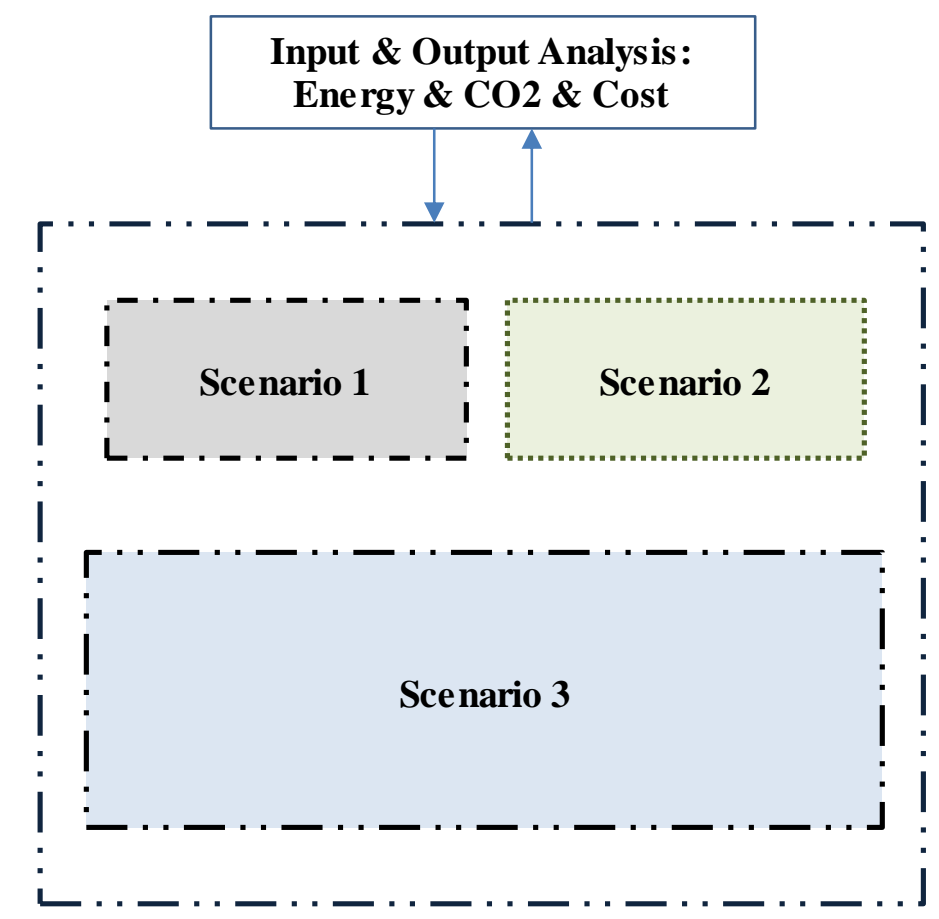

Figure 2. Conceptual model sketch of production of aggregates

In the present study, the total cost is divided into two categories: I. The investment cost which includes the purchase of equipment and the start-up of the plant and II. Operating costs, including the costs of energy consumption and maintenance. The maintenance cost includes the annual costs of service, spare parts, and technical human resources (HR). The computing process of energy consumption and $\mathrm{CO}_{2}$ emissions is based on the following simple relationships which $P$ represents the power rating of each equipment and $h$ is operating hours of each apparatus:

$$
\begin{gathered}
A=P \times h \\
E=A \times E F \times\left(1-\frac{E R}{100}\right)
\end{gathered}
$$

According to the US Environmental Protection Agency (EPA) (AP-42, 1995), in the above-mentioned equation, E stands for emissions, A stands for the amount of activity (energy consumption), EF represents emissions factor, and ER shows the efficiency percentage to reduce emissions. In this study, the effect of the ER reduction factor is ignored in order to increase confidence. Electric and diesel emissions resulting from energy consumption must be estimated separately. Each of these two energy sources has a separate emission factor for $\mathrm{CO}_{2}$. Thus, the total amount of emissions in each scenario is equal to the sum of the two emissions mentioned above.

\section{Scenarios}

Aggregates production methods can be classified under the following three categories: 
- Obtaining natural aggregates from quarries (first scenario)

- Obtaining recycled aggregates from C\&D waste in recycling plants (second scenario)

- Combined method (third scenario)

Natural (virgin) aggregates are crushed and processed in the crushing plants after being extracted and mined (via blasting or drilling way), while recycled aggregates are processed after operating the recycling plants on the landfill sites. Both of these plants include two types of fixed (central) and mobile plants (Zhao et al., 2010). In the present study, the fixed plant type, which is more comprehensive, is investigated.

As mentioned earlier (Fig. 2), the present study follows three scenarios (Fig. 3). Generally, quarry extraction and NA production have become a norm, and owners of stone (sand and gravel) quarries are continuously operating quarries, regardless of the principles of sustainable development (C\&D waste recycling solution). Under such a condition in Iran, the present study focuses on the two scenarios of NA production and RA plant set-up in the landfills. The first scenario is dedicated only to extraction and crushing phases, whereas the second scenario concentrates on the $C \& D$ waste supply to crusher (pre-crushing) and processing phases (after setting up the plant).

The third scenario is a hybrid approach combining scenario 1 and scenario 2 . In other words, it is a combination of NA and RA. Thus, energy consumption, $\mathrm{CO}_{2}$ emissions and costs can be obtained in direct proportion to the hybrid design of aggregates.

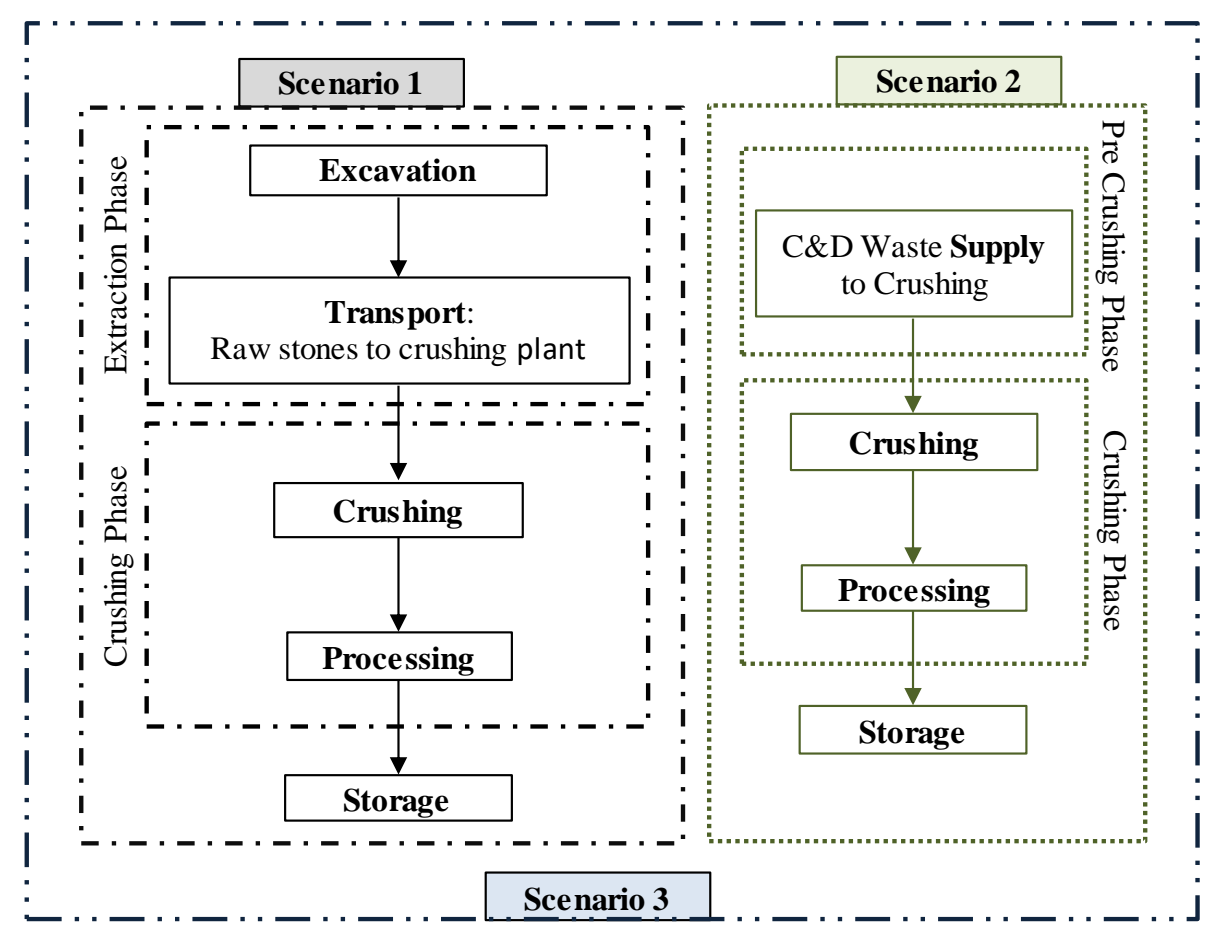

Figure 3. Research scenarios of aggregates production

\section{Description of the production and recycling facility (process)}

After defining the model, objectives, inventory, scope, variables, and relevant data, it is high time that we defined the industry studied. Today, as mentioned before, aggregate production and recycling are defined in the form of crushing and in the central plant and 
also the mobile type. In this research, with regard to the large-scale proposed recycling plan for Iran, only is the central type (fixed) considered. NA production (the first scenario) consists of three stages. In the first step, raw stone materials should be extracted from the mine via explosion and/or drilling methods. In the second step, stone rubbles should be transported to the crushing plant. The third step includes crushing, reducing the size and converting the rubbles into aggregates (gravel and sand). This phase is referred to as the processing or crushing phase. All of these operations are integrated (scenario 1) so as to produce NA, whose schematic process is based on one of the aggregate producers of Tehran quarries and is aimed for basic computations. This producer is the Akam Gravel Company located in the west of Tehran and is a marine quarry with 3 aggregate production lines.

The recycling process of the aggregates is similar to that of the NA production plant. In RA plants, there are only pre-crushing and crushing steps. This plant (scenario 2) requires the initial set-up and installation of equipment. The recycling process of the aggregates is considered for the next computations based on a Chinese proposed plan (a 200-ton / hour plant proposed by Zhengzhou Yifan Machinery Co., Ltd).

\section{Data collected for environmental, energetic and cost analysis}

To assess all of the procedures and processes defined in the life cycle assessment $\left(\mathrm{CO}_{2}\right.$ emissions, energy consumption and cost), the inventory model should be computed and analyzed. For this purpose, both of the production and recycling plants with the capacity of 200 tons / hour are studied. In this type of plants, the complex efficiency depends on the efficiency of each of the related equipment, among which the crushers can be regarded as the main equipment, to determine the overall efficiency based on the importance of the task. Tables 1 and 2 demonstrate the list of equipment for both of the above-mentioned plants along with the required specifications and the related investment costs. Diesel is the fuel consumed in extraction and transportation machinery, while the crusher equipment package utilizes electricity. The work shift of these centers is 8 hours a day (due to environmental hazards such as noise and air pollutions, particularly in the urban suburbs). The basic period of working time in these centers is one year.

Table 1. Main equipment for the 200-ton/h NA plant considered (the first scenario) and the related data

\begin{tabular}{|c|c|c|c|c|c|}
\hline Machine \& model & $\begin{array}{l}\text { Power } \\
\text { (KW) }\end{array}$ & $\begin{array}{c}\text { Number } \\
\text { of items } \\
\text { required }\end{array}$ & $\begin{array}{c}\text { Unit } \\
\text { price } \\
\text { (USD) }\end{array}$ & $\begin{array}{l}\begin{array}{l}\text { Sum } \\
\text { price } \\
\text { (USD) }\end{array} \\
\end{array}$ & $\begin{array}{c}\text { Average } \\
\text { holding cost } \\
\text { (USD/year) }\end{array}$ \\
\hline $\begin{array}{c}\text { Bulldozer. Komatsu D155A-2; } \\
\text { efficiency }=0.71\end{array}$ & 238.6 & 2 & 140541 & 281081 & 23892 \\
\hline $\begin{array}{l}\text { Hydraulic excavator. Komatsu PC 600-7; } \\
\text { efficiency }=0.75\end{array}$ & 287 & 3 & 129730 & 389189 & 35805 \\
\hline $\begin{array}{l}\text { Wheel loader. Komatsu WA420-3; } \\
\text { efficiency }=0.75\end{array}$ & 162 & 2 & 67027 & 134054 & 12065 \\
\hline $\begin{array}{l}\text { Rigid dump truck. Komatsu HD325-6; } \\
\text { efficiency }=0.8\end{array}$ & 364 & 1 & 135135 & 135135 & 11486 \\
\hline $\begin{array}{l}\text { Lorry truck. Benz Wh 2624; efficiency }= \\
\qquad 0.82\end{array}$ & 179 & 4 & 56757 & 227027 & 18843 \\
\hline $\begin{array}{l}\text { Backhoe loader. HEPCO B90B; } \\
\text { efficienc y }=0.65\end{array}$ & 72 & 1 & 29189 & 29189 & 2277 \\
\hline
\end{tabular}




\begin{tabular}{cccccc}
\hline Primary-jaw crusher & 165 & 1 & 31216 & 31216 & 4865 \\
Secondary-hydro cone crusher & 125 & 2 & 26486 & 52973 & 13946 \\
Tertiary-impact crusher & 195 & 1 & 26351 & 26351 & 7622 \\
Vibrating feeder & 16 & 2 & 10811 & 21622 & 2789 \\
Vibrating screening & 19 & 3 & 15405 & 46216 & 4962 \\
Bucket-typed sand washing machine & 18 & 1 & 12162 & 12162 & 1459 \\
pan-typed aggregate washing machine & 20 & 3 & 7568 & 22703 & 2919 \\
Control panel & - & 1 & 19595 & 19595 & 85 \\
Steel structure- 7.85 tons & - & 1 & 8486 & 8486 & 950 \\
Conveyor belt $1.2 \times 35$ & 18 & 4 & 12297 & 49189 & 7568 \\
Conveyor belt $1.2 \times 21$ & 12.5 & 4 & 7095 & 28378 & 4541 \\
Conveyor belt $1 \times 15$ & 8 & 3 & 4622 & 13865 & 2311 \\
Conveyor belt $1 \times 8$ & 6.5 & 2 & 2270 & 4541 & 800 \\
Conveyor belt $1.2 \times 4$ & 5 & 1 & 1081 & 1081 & 200 \\
Conveyor belt $1 \times 3.5$ & 4 & 1041 & 2081 & 341 \\
\hline \multicolumn{5}{c}{ Average useful life of plant $=20$ years } \\
Total pric e= Invest (USD) \\
Total holding cost (USD / year) \\
Human resource salary (USD / year) \\
Maintenance (USD / year) \\
\hline
\end{tabular}

Table 2. Main equipment for the 200-ton/h RA plant considered (the second scenario) and the related data

\begin{tabular}{cccccc}
\hline Machine \& model & $\begin{array}{c}\text { Power } \\
\text { (KW) }\end{array}$ & $\begin{array}{c}\text { Number } \\
\text { of items } \\
\text { required }\end{array}$ & $\begin{array}{c}\text { Unit } \\
\text { price } \\
\text { (USD) }\end{array}$ & $\begin{array}{c}\text { Sum } \\
\text { price } \\
\text { (USD) }\end{array}$ & $\begin{array}{c}\text { Average } \\
\text { holding cost } \\
\text { (USD/year) }\end{array}$ \\
\hline Hydraulic excavator. Komatsu PC 200-7; & 107 & 1 & 47568 & 47568 & 3948 \\
efficiency = 0.7 & & & & & \\
Wheel loader. VOLVO L120F; & 179 & 1 & 105405 & 105405 & 9276 \\
efficiency = 0.73 & 15 & 1 & 15860 & 15860 & 1849 \\
Vibrating feeder & 90 & 1 & 66270 & 66270 & 8757 \\
Primary-jaw crusher & 250 & 1 & 57820 & 57820 & 10541 \\
Secondary- impact crusher & 30 & 1 & 31730 & 31730 & 2432 \\
Vibrating screening & 3 & 1 & 11200 & 11200 & 1622 \\
Magnetic separator & 5.5 & 2 & 11670 & 23340 & 3892 \\
Soft products separator & 85 & 1 & 67000 & 67000 & 6486 \\
Dust collector & - & 1 & 15240 & 15240 & 85 \\
Control panel & - & 1 & 7300 & 7300 & 715 \\
Steel structure- 4 tons & 7.5 & 1 & 6850 & 6850 & 595 \\
Conveyor belt $1 \times 11$ & 5.5 & 1 & 8970 & 8970 & 541 \\
Conveyor belt $1.2 \times 10$ & 11 & 1 & 9250 & 9250 & 1027 \\
Conveyor belt $1 \times 19$ & 15 & 1 & 11050 & 11050 & 1351 \\
Conveyor belt $1 \times 25$ & 4 & 1 & 6545 & 6545 & 541 \\
Conveyor belt $1 \times 10$ & 7.5 & 1 & 6500 & 6500 & 865 \\
Conveyor belt $0.8 \times 16$ & 7.5 & 2 & 6120 & 12240 & 2162 \\
Conveyor belt $0.65 \times 20$ & 5.5 & 1 & 4600 & 4600 & 649 \\
Conveyor belt $0.65 \times 12$ & 5.5 & 1 & 5170 & 5170 & 811 \\
Conveyor belt $0.65 \times 15$ & 5.5 & 1 & 5470 & 5470 & 973 \\
Conveyor belt $0.65 \times 18$ & & & & & \\
\hline
\end{tabular}




\begin{tabular}{cc}
\hline \multicolumn{2}{c}{ Average useful life of plant = 20 years } \\
\hline Total price = Invest (USD) & 525378 \\
Total yearly price = annual equivalent invest (USD) & $\mathbf{2 6 2 6 9}$ \\
Total holding cost (USD / year) & 59116 \\
Human resource salary (USD / year) & 120000 \\
Maintenance (USD / year) & $\mathbf{1 7 9 1 1 6}$ \\
\hline
\end{tabular}

According to the International Energy Agency (IEA, 2014), since a large part of energy resources in Iran is crude oil (one of the fossil fuels), the kilogram oil equivalent (kgoe) unit is employed for energy computation (as electrical to thermal conversion efficiency) to integrate the data obtained. Therefore, a conversion coefficient of 0.29 is utilized to convert the final electricity demand in $\mathrm{kW} h$ to primary energy in kgoe. Similarly, $\mathrm{CO}_{2}$ eq / kgoe is used for $\mathrm{CO}_{2}$ emissions. The emission conversion factor of $1.2\left(\mathrm{~kg} \mathrm{CO} \mathrm{CO}_{2} \mathrm{eq} / \mathrm{kgoe}\right)$ is used for the electricity-powered apparatus (Coelho and de Brito, 2013). For the diesel-powered machines, $0.086(\mathrm{kgoe} / \mathrm{kW} \mathrm{h})$ was considered as the final/primary energy conversion factor and $3.032\left(\mathrm{~kg} \mathrm{CO}_{2} \mathrm{eq} / \mathrm{kgoe}\right)$ was considered as the specific $\mathrm{CO}_{2}$ eq emission factor (Coelho and de Brito, 2013). Table 3 summarizes the above-mentioned factors influencing the conversion of heat and electricity units to fossil fuels and $\mathrm{CO}_{2}$ emissions.

\section{Results and discussions}

As mentioned in the second and the third sections, a simplified life cycle analysis (LCA) is used for identifying and measuring the impact of aggregates production on the environment. Accordance to relations 1 and 2, the energy consumption and $\mathrm{CO}_{2}$ emissions rates are computed for the both of scenarios 1 and 2 in the life cycles include of pre crushing (extraction) and crushing. Tables 4 and 5 show the results of equivalent energy (oil) consumption and equivalent $\mathrm{CO}_{2}$ emissions and also the cost values of energy consumption for each scenario.

Table 3. Unit conversion factors in energy consumption and $\mathrm{CO}_{2}$ emissions

\begin{tabular}{|c|c|c|c|}
\hline \multirow{2}{*}{ Source } & \multicolumn{2}{|c|}{ Energy } & \multirow{2}{*}{$\begin{array}{c}\text { Emission } \\
\mathrm{CO}_{2} \mathrm{eq} / \mathrm{kgoe} \\
\end{array}$} \\
\hline & Final (KW h) & Primary (kgoe) & \\
\hline Electricity & 1 & 0.29 & 1.2 \\
\hline Diesel & 1 & 0.086 & 3.032 \\
\hline
\end{tabular}

Table 4. Energy consumption, $\mathrm{CO}_{2}$ emissions and energy cost for the NA production plant (the first scenario)

\begin{tabular}{cccc}
\hline Step (process) & Machine \& model & $\begin{array}{c}\text { Power } \\
\text { (KW) }\end{array}$ & $\begin{array}{c}\text { Energy consumption } \\
\text { (KW h) }\end{array}$ \\
\hline & Bulldozer. Komatsu D155A-2 & 238.6 & 339 \\
Extraction \& & Hydraulic excavator. Komatsu PC 600-7 & 287 & 646 \\
Mining & Wheel loader. Komatsu WA420-3 & 162 & 243 \\
(energy source & Rigid dump truck. Komatsu HD325-6 & 364 & 291 \\
is diesel) & Lorry truck. Benz Wh 2624 & 179 & 587 \\
& Backhoe loader. HEPCO B90B & 72 & 47 \\
& & & \\
\hline
\end{tabular}




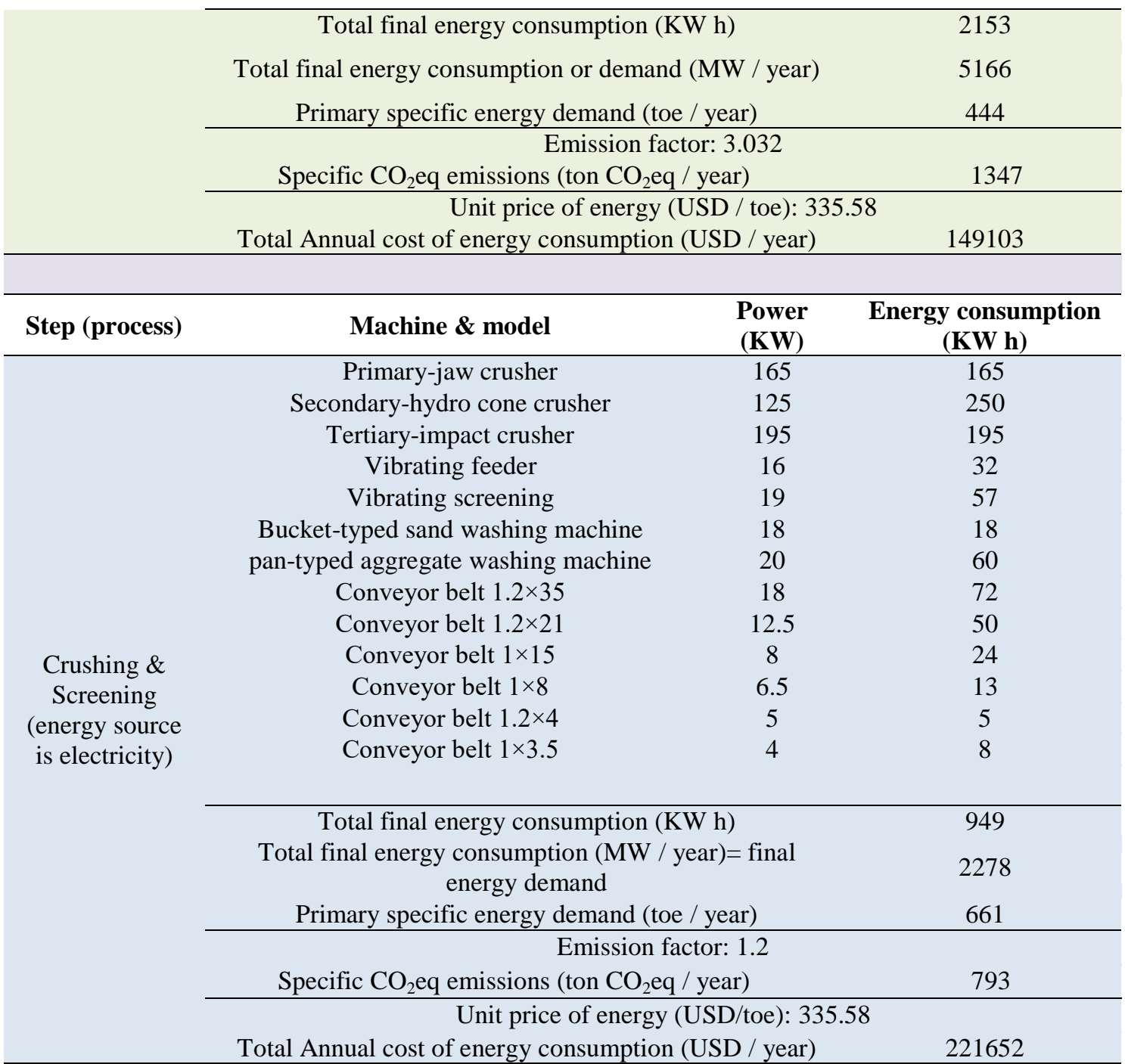

Table 5. Energy consumption, $\mathrm{CO}_{2}$ emissions and energy cost for the aggregates recycling plant (the second scenario)

\begin{tabular}{|c|c|c|c|}
\hline Step (process) & Machine \& model & $\begin{array}{c}\text { Power } \\
(\text { KW) }\end{array}$ & $\begin{array}{c}\text { Energy consumption } \\
(\mathrm{KW} \mathrm{h})\end{array}$ \\
\hline \multirow{9}{*}{$\begin{array}{l}\text { Pre Crushing } \\
\text { (energy source is } \\
\text { diesel) }\end{array}$} & Hydraulic excavator. Komatsu PC 200-7 & 107 & 75 \\
\hline & Wheel loader. VOLVO L120F & 179 & 131 \\
\hline & \multirow{3}{*}{\multicolumn{2}{|c|}{$\begin{array}{l}\text { Total final energy consumption (KW h) } \\
\text { Total final energy consumption or demand (MW / year) } \\
\text { Primary specific energy demand (toe / year) }\end{array}$}} & 206 \\
\hline & & & 493 \\
\hline & & & 42 \\
\hline & \multicolumn{3}{|c|}{ Emission factor: 3.032} \\
\hline & \multicolumn{2}{|c|}{ Specific $\mathrm{CO}_{2} \mathrm{eq}$ emissions (ton $\mathrm{CO}_{2} \mathrm{eq} /$ year) } & 129 \\
\hline & \multicolumn{3}{|c|}{ Unit price of energy (USD / toe): 335.5} \\
\hline & \multicolumn{2}{|c|}{ Total Annual cost of energy consumption (USD / year) } & 14239 \\
\hline Step (process) & Machine \& model & $\begin{array}{c}\text { Power } \\
(\text { KW) }\end{array}$ & $\begin{array}{c}\text { Energy consumption } \\
(\mathrm{KW} \mathrm{h})\end{array}$ \\
\hline Crushing \& & Vibrating feeder & 15 & 15 \\
\hline Screening & Primary-jaw crusher & 90 & 90 \\
\hline (energy source is & Secondary- impact crusher & 250 & 250 \\
\hline
\end{tabular}




\begin{tabular}{ccc}
\hline electricity) & 30 & 30 \\
Vibrating screening & 3 & 3 \\
Magnetic separator & 5.5 & 11 \\
Soft products separator & 85 & 85 \\
Dust collector & 7.5 & 7.5 \\
Conveyor belt $1 \times 11$ & 5.5 & 5.5 \\
Conveyor belt $1.2 \times 10$ & 11 & 11 \\
Conveyor belt $1 \times 19$ & 15 & 15 \\
Conveyor belt $1 \times 25$ & 4 & 4 \\
Conveyor belt $1 \times 10$ & 7.5 & 7.5 \\
Conveyor belt $0.8 \times 16$ & 7.5 & 15 \\
Conveyor belt $0.65 \times 20$ & 5.5 \\
Conveyor belt $0.65 \times 12$ & 5.5 \\
Conveyor belt $0.65 \times 15$ & 5.5 \\
Conveyor belt $0.65 \times 18$ & 5.5 & 566 \\
Total final energy consumption (KW h) & 1358 \\
Total final energy consumption or demand (MW / year) & 394 \\
Primary specific energy demand (toe / year) & \\
Total Annual cost of energy consumption (USD / year) & 132197 \\
\hline Specific CO ${ }_{2}$ eq emissions (ton CO eq / year) & 473 \\
\hline
\end{tabular}

The proper judgment on the scenarios requires a precise evaluation of the total cost. As mentioned above, the third scenario is a hybrid scenario, i.e. the combination of NA and RA with a predetermined mixing percentage based on qualitative and experimental considerations. In this research which is subject to a moderate approach, a mixing ratio of $50 \%$ is assumed for the aggregates. Hence, the average results of environmental impacts (energy consumption and $\mathrm{CO}_{2}$ emissions) and cost analysis (investment and energy consumption) of the scenario 1 and scenario 2 will be assigned for the third scenario. Table 6 summarizes the data computed of energe consumption, $\mathrm{CO}_{2}$ emissions and cost values.

Table 6. Energy consumption, $\mathrm{CO}_{2}$ emissions and cost summarized data for scenarios

\begin{tabular}{|c|c|c|c|c|c|}
\hline $\begin{array}{c}\text { Cost } \\
\text { (USD/year) }\end{array}$ & Phase & $\begin{array}{c}\text { Aggregate } \\
\text { obtaining type }\end{array}$ & $\begin{array}{l}\text { Processing } \\
\text { step }\end{array}$ & $\begin{array}{c}\text { Primary specific } \\
\text { energy demand } \\
\text { (toe/year) }\end{array}$ & $\begin{array}{c}\text { Specific } \mathrm{CO}_{2} \mathrm{eq} \\
\text { emissions (ton } \\
\mathrm{CO}_{2} \mathrm{eq} / \mathrm{year} \text { ) }\end{array}$ \\
\hline 76807 & $\begin{array}{l}\text { Investment } \\
\text { cost }\end{array}$ & \multirow{3}{*}{ Scenario 1} & $\begin{array}{l}\text { Extraction } \\
\& \text { Mining }\end{array}$ & 444 & 1347 \\
\hline 519725 & $\begin{array}{l}\text { Maintenance } \\
\text { cost }\end{array}$ & & $\begin{array}{l}\text { Crushing \& } \\
\text { Screening }\end{array}$ & 661 & 793 \\
\hline 370755 & Energy cost & & Total & 1105 & 2140 \\
\hline 26269 & $\begin{array}{l}\text { Investment } \\
\text { cost }\end{array}$ & \multirow{3}{*}{ Scenario 2} & $\begin{array}{c}\text { Pre } \\
\text { Crushing }\end{array}$ & 42 & 129 \\
\hline 179116 & $\begin{array}{l}\text { Maintenance } \\
\text { cost }\end{array}$ & & $\begin{array}{l}\text { Crushing \& } \\
\text { Screening }\end{array}$ & 394 & 473 \\
\hline 146436 & Energy cost & & Total & 436 & 602 \\
\hline 51538 & $\begin{array}{l}\text { Investment } \\
\text { cost }\end{array}$ & \multirow{3}{*}{ Scenario 3} & $\begin{array}{l}\text { Extraction } \\
\& \text { Mining }\end{array}$ & 243 & 738 \\
\hline 349421 & $\begin{array}{l}\text { Maintenance } \\
\text { cost }\end{array}$ & & $\begin{array}{l}\text { Crushing \& } \\
\text { Screening }\end{array}$ & 527 & 633 \\
\hline 258595 & Energy cost & & Total & 770 & 1371 \\
\hline
\end{tabular}


The values of environmental variables computed for each scenario are indicated by bar charts in Fig. 4. The horizontal axis of this diagram demonstrates the scenarios involved in different phases. Moreover, the upper and bottom vertical semi-axis represent the yearly values of the energy consumption and $\mathrm{CO}_{2}$ emissions respectively. ccording to Fig. 4, the first scenario is in a crisis situation compared with scenario 2 and scenario 3. Although the third scenario is in a balanced position towards the first scenario which is easily visible in the final situation graph (Fig. 5), the second scenario includes the lower values.

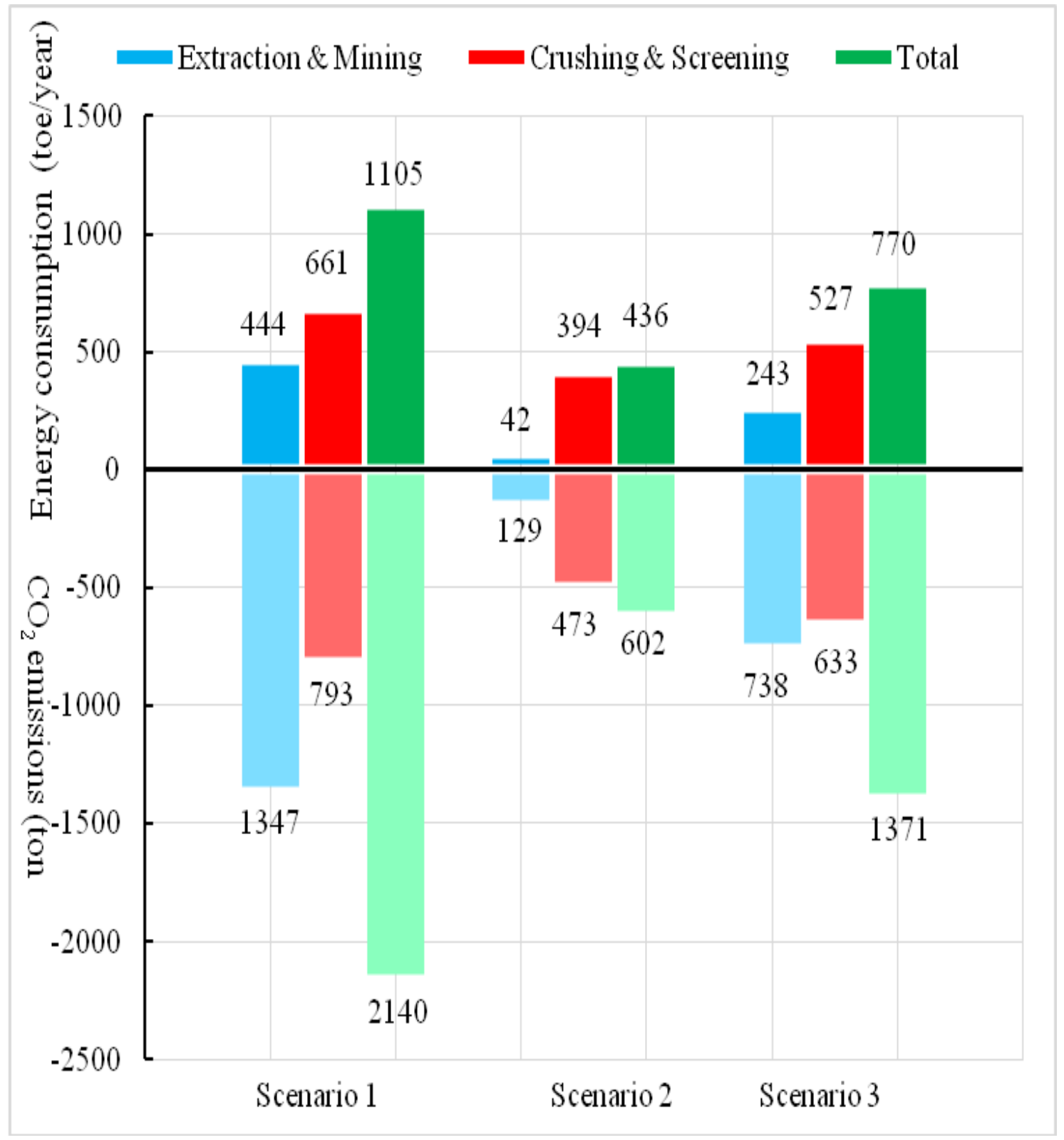

Figure 4. Environment impact bar charts of research scenarios 

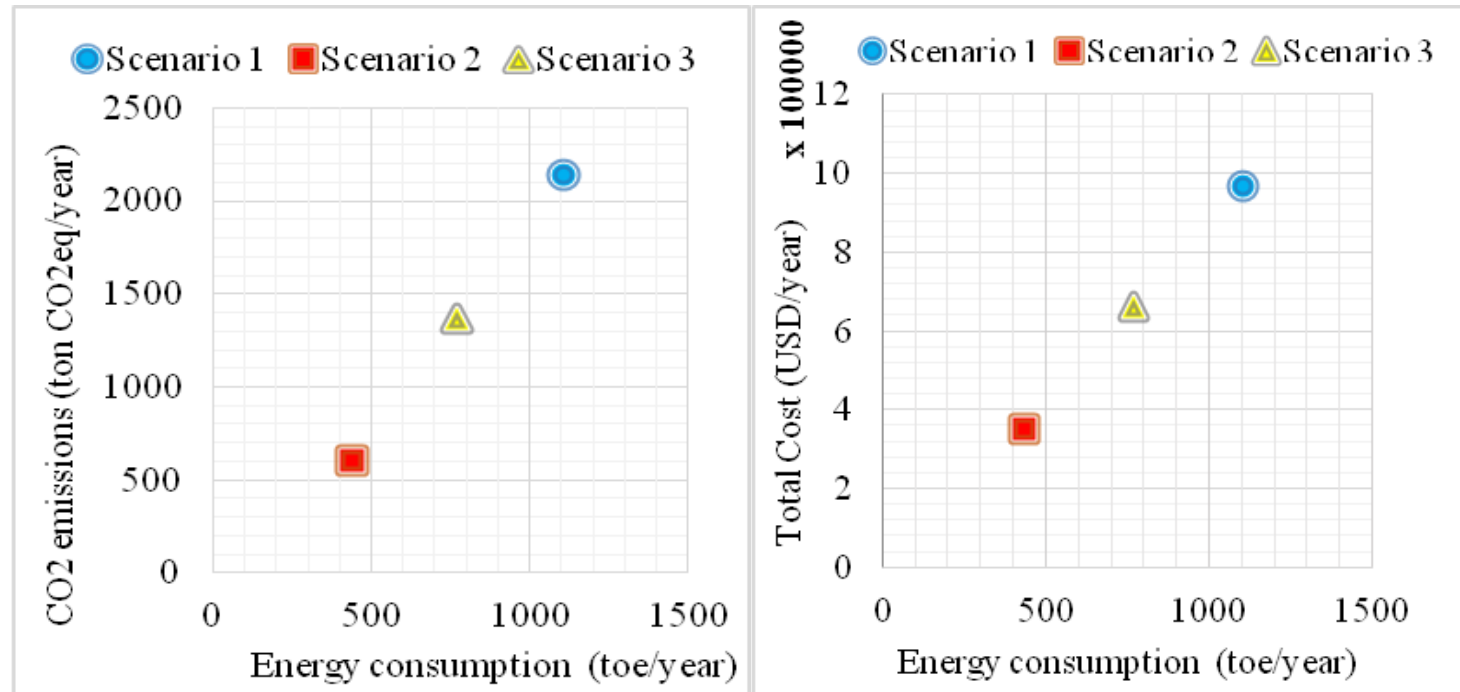

Figure 5. Final situation ( $\mathrm{CO}_{2}$ emissions and cost vs. energy consumption) chart of research scenarios

According to Table 6 and Fig. 4, the major energy consumption in the first scenario is related to the crushing phase, which leads to an increase in the total energy consumption. However, the rate of $\mathrm{CO}_{2}$ emissions in the extraction phase (pre-crushing) is more than that of the crushing phase because the extraction phase employs the diesel machinery which has a higher emission factor compared to the electric apparatus. Since there is not a large number of diesel machines in the second scenario, energy consumption is very low in the pre-crushing phase. In this scenario, the wheel loader and the hydraulic excavator are utilized to prepare and feed the C\&D wastes to the crusher; therefore, the energy consumption in this scenario is assigned to the precrushing phase. In the second scenario, the major energy consumption is related to the crushing phase. Similarly, in the third scenario, the major energy consumption and $\mathrm{CO}_{2}$ emissions are related to the crushing and the extraction phases, respectively. In order to reduce the environmental consequences resulting from the exploitation of stone quarries in Iran and the world, scenarios 2 and 3 should be selected. It must be noted that scenario 2 is the eco-friendly choice.

In point of fact, the computations shown are related to the annual performance (300 day $\times 8$ hour) of just one plant with a capacity of 200 tons per hour. This means that each of the resultant values is related to the annual production $(200 \times 8 \times 300=480000$ tons) of just one plant. To obtain the values for each ton of aggregates, the results need to be divided by 480000 , which is done in Table 7 . These amounts fall within the ranges which have been used in one of the environmental studies related to life cycle concrete block (Oliveira et al., 2016).

It has been reported that there are 1345 active (operating) sand and gravel quarries in Iran (SCI, 2016). Multiplying this number by the annual $\mathrm{CO}_{2}$ emissions will result in a huge number which shows the total value of the first scenario for the whole country. Based on the number of Iranian active quarries, the annual values of energy consumption, $\mathrm{CO}_{2}$ emissions and cost in the present situation (the overall scenario 1) and other scenarios are summarized in Table 8. 
Table 7. Comparison of the energy consumption and cost of each ton of aggregates in each scenario

\begin{tabular}{ccccc}
\hline $\begin{array}{c}\text { Aggregate } \\
\text { obtaining } \\
\text { type }\end{array}$ & $\begin{array}{c}\text { Final Energy } \\
\text { Demand } \\
\text { (MJ/ton) }\end{array}$ & $\begin{array}{c}\text { Primary Specific } \\
\text { Energy Demand } \\
\text { (kgoe/ton) }\end{array}$ & $\begin{array}{c}\text { Specific CO } \mathbf{C O}_{2} \mathbf{e q} \\
\text { emissions } \\
\left.\mathbf{C O}_{2} \mathbf{e q} / \text { ton }\right)\end{array}$ & $\begin{array}{c}\text { Total cost } \\
\text { (USD/ton) }\end{array}$ \\
\hline Scenario 1 & 55.83 & 2.30 & 4.45 & 2.02 \\
Scenario 2 & 13.89 & 0.91 & 1.25 & 0.73 \\
Scenario 3 & 34.86 & 1.61 & 2.85 & 1.37 \\
\hline
\end{tabular}

However, it is a lofty ideal that if the recycling plants are constructed in proportion to the number of these active quarries (the overall scenario 2), there will be a significant difference between the overall scenario 1 and the overall scenario 2. Likewise, via the mixing ratio of $50 \%$, the overall scenario 3 could also be established, considerably saving the energy consumption, $\mathrm{CO}_{2}$ emissions and the related costs. This hybrid scenario is achievable by strategic planning and governmental support. As Table 8 illustrates, the overall scenario 3, which is a conservative approach, leads to $30 \%, 36 \%$ and $32 \%$ reductions in energy consumption, $\mathrm{CO}_{2}$ emissions and cost, respectively, compared to the overall scenario 1 (the current situation in Iran). These results are similar to those of container glass recycling, leading to significant reductions of $27 \%$ and $37 \%$ in energy consumption and GHG emissions, respectively (Vossberg et al., 2014). Implementing this policy and analyzing these values for the United States, which produces 2 billion tons of aggregates annually (Harrington, 2005), will yield more tangible outcomes. If the rate of $\mathrm{CO}_{2}$ emissions in the overall scenario 1 is analyzed for the next 10 years in Iran, regardless of the annual population growth which is the growth factor of C\&D wastes (Huang et al., 2013), Iran's share in global pollution and $\mathrm{CO}_{2}$ emissions in the aggregate sector will be determined, which will undoubtedly be an enormous number. $\mathrm{CO}_{2}$ emission is a consequence of the energy consumption and the energy consumption is achieved by converting the final energy to primary energy. Therefore, the convertion factors of energy and emission are the sensitive parameteres. Thus, a tiny change in the rates of convertion factors woluld make more significant effect on the results towards to other parameteres such as power of apparatus in any scenario.

Table 8. Comparison between the overall scenarios in Iran

\begin{tabular}{cccc}
\hline $\begin{array}{c}\text { Aggregate obtaining } \\
\text { type }\end{array}$ & $\begin{array}{c}\text { Primary specific } \\
\text { energy demand } \\
\text { (toe/year) }\end{array}$ & $\begin{array}{c}\text { Specific CO } \mathbf{C O}_{\mathbf{2}} \mathbf{e q} \\
\text { emissions (ton } \\
\left.\mathbf{C O}_{\mathbf{2}} \mathbf{e q} / \mathbf{y e a r}\right)\end{array}$ & $\begin{array}{c}\text { Total annual cost } \\
\text { (Million USD/year) }\end{array}$ \\
\hline Overall first scenario & 1485979.62 & 2877981.95 & $1,301.001$ \\
Overall second scenario & 586911.80 & 808842.51 & 473.198 \\
Overall third scenario & 1036445.71 & 1843412.23 & 887.10 \\
\hline $\begin{array}{c}\text { Saving percent (third } \\
\text { scenario/first scenario) }\end{array}$ & $30 \%$ & $36 \%$ & $32 \%$ \\
\hline
\end{tabular}




\section{Conclusions}

The economic assessment of the production of aggregates was the main objective of the present research. Three important variables in this study were energy consumption, $\mathrm{CO}_{2}$ emissions and cost. Furthermore, three scenarios were evaluated. The first scenario focused on the production of natural aggregates (NA) by raw stone extraction from quarries as well as processing the aggregates in the crushing plants. This scenario consists of the extraction and crushing phases with diesel-electric machinery and equipment. As Iranians do not have any experience in the recycled aggregate (RA) industry, the second scenario is the solution by which RA is obtained from construction and demolition $(C \& D)$ waste. This scenario suggests operating the recycling plants on the landfill sites of cities, where landfills have created an environmental crisis. This scenario also has two phases: landfill or pre-crushing (supplying C\&D wastes to crusher) and processing (crushing); furthermore, the majority of equipment in this scenario consumes electricity. The third scenario (the hybrid scenario) is a solution similar to the second scenario but suggests the combination of NA and RA with a mixing ratio. This ratio depends on the aggregate usage type (buildings, concrete, roads construction, and pavements) and needs related experimental research. In the present research, the mixing ratio of $50 \%$ was assumed for the aggregates.

Life cycle assessment (LCA) approach as a basic concept was partially applied to assess the environmental impacts. In each scenario, the variables were analyzed for different phases of the life cycle of NA and RA plants. The total cost includes investment, energy, and maintenance costs. Analysis of the results revealed that the current situation in Iran (the first scenario) is the most intense policy that could cause excessive $\mathrm{CO}_{2}$ emissions and quickly reduce the aggregate resources of next generations (thus, this scenario is against sustainable development). In addition, this scenario puts municipalities under pressure to provide sufficient landfills. In this research, the approximate rates of 1.48 million tons oil equivalent/year, 2.88 million tons $\mathrm{CO}_{2} \mathrm{eq}$ emissions / year and 1301 million USD / year are estimated for the aggregate production sector in Iran (the first scenario). This policy, with regard to the effects of population growth and $\mathrm{C} \& \mathrm{D}$ waste growth, will soon lead to intense environmental hazards.

The second scenario is the most ideal solution; however, high technical specification of aggregates is required in the majority of applications. Accordingly, the use of RA alone is probably not satisfactory. Therefore, it is problematic to implement this scenario alone. The third scenario (the hybrid approach) is more acceptable due to reducing energy consumption, $\mathrm{CO}_{2}$ emissions and costs and taking technical-qualitative advantages of NA and RA. It was found that the third scenario will reduce the annual energy consumption, $\mathrm{CO}_{2}$ emissions and cost by $30 \%, 36 \%$ and $32 \%$, respectively, compared to the first scenario. Last but not least, it is worth mentioning that implementing this scenario requires perfect financial support from the government. Generally, Combination of NA and RA is an ideal option while natural aggregates production has the greatest environmental impact. Thus for the Iran situation, use of concrete and other construction product of aggregates need a suitable life cycle assessment technique which can consider the energy consumption, $\mathrm{CO}_{2}$ emissions and cost simultaneously. Experimental and mathematical study for determining the optimal ratio of NA and RA combination for each construction application aggregates is one of the most important recommendations and future development needs to be incorporated that would pave the way for future researchers. 


\section{REFERENCES}

[1] AP-42. (1995): Compilation of Air Pollutant Emission Factors: Introduction $\left(5^{\text {th }}\right.$ ed. Vol. 1). - Available at: https://www3.epa.gov/ttnchie1/ap42/c00s00.pdf.

[2] Arulrajah, A., Piratheepan, J., Disfani, M., Bo, M. (2013): Geotechnical and Geoenvironmental Properties of Recycled Construction and Demolition Materials in Pavement Subbase Applications. - Journal of Materials in Civil Engineering 25(8): 10771088.

[3] Arulrajah, A., Disfani, M. M., Horpibulsuk, S., Suksiripattanapong, C., Prongmanee, N. (2014): Physical properties and shear strength responses of recycled construction and demolition materials in unbound pavement base/subbase applications. - Construction and Building Materials 58: 245-257.

[4] Chau, C. K., Leung, T. M., Ng, W. Y. (2015): A review on life cycle assessment, life cycle energy assessment and life cycle carbon emissions assessment on buildings. Applied Energy 143: 395-413. DOI: 10.1016/j.apenergy.2015.01.023.

[5] Coelho, A., de Brito, J. (2013): Environmental analysis of a construction and demolition waste recycling plant in Portugal-Part I: energy consumption and $\mathrm{CO}_{2}$ emissions. Waste management 33(5): 1258-1267.

[6] Harrington, J. (2005): Recycled Roadways, Public Roads. U.S. - Department of Transportation. Federal Highway Administration, Jan/Feb 2005, 68, No. 4.

[7] Huang, T., Shi, F., Tanikawa, H., Fei, J., Han, J. (2013): Materials demand and environmental impact of buildings construction and demolition in China based on dynamic material flow analysis. - Resources, Conservation and Recycling 72: 91-101.

[8] Huang, W. L., Lin, D. H., Chang, N. B., Lin, K. S. (2002): Recycling of construction and demolition waste via a mechanical sorting process. - Resources, Conservation and Recycling 37(1): 23-37.

[9] IEA. (2014): Key Energy Statistics for Iran. International Energy Agency. - Available at: http://www.iea.org/countries/non-membercountries/iranislamicrepublicof/

[10] INSO. (2015): Concrete Aggregates-Specifications, standard No. 302. 3rd Revision. Iranian National Standardization Organization, Tehran, Iran.

[11] Islam, H., Jollands, M., Setunge, S. (2015a): Life cycle assessment and life cycle cost implication of residential buildings - a review. - Renewable and Sustainable Energy Reviews 42: 129-140. DOI: 10.1016/j.rser.2014.10.006.

[12] Islam, H., Jollands, M., Setunge, S., Haque, N., Bhuiyan, M. A. (2015b): Life cycle assessment and life cycle cost implications for roofing and floor designs in residential buildings. - Energy and Buildings 104: 250-263. DOI:10.1016/j.enbuild.2015.07.017.

[13] Lawania, K., Sarker, P., Biswas, W. (2015): Global warming implications of the use of by-products and recycled materials in western Australia's housing sector. - Materials, 8(10): 6909-6925. DOI: 10.3390/ma8105347.

[14] Liang, Y. C., Ye, Z. M., Vernerey, F., Xi, Y. (2013): Development of Processing Methods to Improve Strength of Concrete with 100\% Recycled Coarse Aggregate. Journal of Materials in Civil Engineering 27(5).

[15] Mangan, S. D., Oral, G. K. (2016): Assessment of residential building performances for the different climate zones of Turkey in terms of life cycle energy and cost efficiency. Energy and Buildings 110: 362-376. DOI: 10.1016/j.enbuild.2015.11.002.

[16] Oh, D. Y., Noguchi, T., Kitagaki, R., Park, W. J. (2014): $\mathrm{CO}_{2}$ emission reduction by reuse of building material waste in the Japanese cement industry. - Renewable and Sustainable Energy Reviews 38: 796-810.

[17] Oliveira, L. S., Pacca, S. A., John, V. M. (2016): Variability in the life cycle of concrete block $\mathrm{CO}_{2}$ emissions and cumulative energy demand in the Brazilian Market. Construction and Building Materials 114: 588-594. 
[18] Petkovic, G., Engelsen, C. J., Håøya, A. O., Breedveld, G. (2004): Environmental impact from the use of recycled materials in road construction: method for decision-making in Norway. - Resources, Conservation and Recycling 42(3): 249-264.

[19] Ping, W., Yidong, X. (2011): Life cycle assessment of recycled aggregate concrete containing fly ash. - 2011 Second International Conference on Mechanic Automation and Control Engineering (MACE). Hohhot, China.

[20] PMO. (2013): Road General Technical Specification No. 101. Second Revision, Management and Planning Organization of Iran. - Technical and administrative system, Tehran, Iran. Available at:

http://bpms.mporg.ir/Portal/View/Viewer.aspx?ObjectType=SearchForm\&ObjectId=6d4 88941-3b4d-407c-a16d-e90861c1f7f9\&DashboardId=cf271f81-bb08-4b64-89b0ac690b57bc93

[21] Ristimäki, M., Säynäjoki, A., Heinonen, J., Junnila, S. (2013): Combining life cycle costing and life cycle assessment for an analysis of a new residential district energy system design. - Energy 63: 168-179. 10.1016/j.energy.2013.10.030.

[22] Sabai, M. M., Cox, M. G. D. M., Mato, R. R., Egmond, E. L. C., Lichtenberg, J. J. N. (2013): Concrete block production from construction and demolition waste in Tanzania. Resources, Conservation and Recycling 72: 9-19.

[23] Saghafi, M. D., Teshnizi, Z. S. H. (2011): Recycling value of building materials in building assessment systems. - Energy and Buildings 43(11): 3181-3188.

[24] SCI. (2016): Summary the results of census of mines operating in the country of 2015. Office of Industry, Mining and Infrastructure, Statistical Center of Iran, Tehran, Iran. Available online at: https://amar.org.ir/Portals/0/Files/abstract/1394/ch_ntaamdhbbk_93.pdf

[25] Sieffert, Y., Huygen, J. M., Daudon, D. (2014): Sustainable construction with repurposed materials in the context of a civil engineering-architecture collaboration. - Journal of Cleaner Production 67: 125-138.

[26] Tam, V. W. (2008): Economic comparison of concrete recycling: A case study approach. - Resources, Conservation and Recycling 52(5): 821-828.

[27] Tam, V. W., Tam, C. M. (2006): A review on the viable technology for construction waste recycling. - Resources, Conservation and Recycling 47(3): 209-221.

[28] Tam, V. W., Tam, L., Le, K. N. (2010): Cross-cultural comparison of concrete recycling decision-making and implementation in construction industry. - Waste management 30(2): 291-297.

[29] TUPRC. (2013): City Knowledge Booklets, No. 199: Check the status of legal and organizational structure of waste management in the country. - Tehran Urban Planning \& Research Center, Tehran, Iran. Available online at: http://pasmand.tehran.ir/Portals/0/Document/maghale/takhasosi/waste\%20structure.pdf

[30] Vossberg, C., Mason-Jones, K., Cohen, B. (2014): An energetic life cycle assessment of C\&D waste and container glass recycling in Cape Town, South Africa. - Resources, Conservation and Recycling 88: 39-49.

[31] Woon, K. S., Lo, I. M. (2016): An integrated life cycle costing and human health impact analysis of municipal solid waste management options in Hong Kong using modified ecoefficiency indicator. - Resources, Conservation and Recycling 107: 104-114.

[32] Yin, S., Tuladhar, R., Sheehan, M., Combe, M., Collister, T. (2016): A life cycle assessment of recycled polypropylene fibre in concrete footpaths. - Journal of Cleaner Production 112: 2231-2242.

[33] Zhao, W., Leeftink, R. B., Rotter, V. S. (2010): Evaluation of the economic feasibility for the recycling of construction and demolition waste in China-The case of Chongqing. Resources, Conservation and Recycling 54(6): 377-389. 